This item was submitted to Loughborough's Research Repository by the author.

Items in Figshare are protected by copyright, with all rights reserved, unless otherwise indicated.

\title{
Looking like a regional organization? The European model of regional integration and the West African Economic and Monetary Union (WAEMU)
}

PLEASE CITE THE PUBLISHED VERSION

https://doi.org/10.1080/09557571.2019.1634676

\section{PUBLISHER}

Taylor \& Francis () 2019 Department of Politics and International Studies

\section{VERSION}

AM (Accepted Manuscript)

\section{PUBLISHER STATEMENT}

This is an Accepted Manuscript of an article published by Taylor \& Francis in Cambridge Review of International Affairs on $12 \mathrm{Jul}$ 2019, available online: https://doi.org/10.1080/09557571.2019.1634676

\section{LICENCE}

CC BY-NC-ND 4.0

\section{REPOSITORY RECORD}

Piccolino, Giulia. 2019. "Looking Like a Regional Organization? the European Model of Regional Integration and the West African Economic and Monetary Union (WAEMU)". Loughborough University.

https://hdl.handle.net/2134/37553. 


\title{
Looking like a regional organization? The European model of regional integration and the West African Economic and Monetary Union (WAEMU)*
}

Giulia Piccolino, Loughborough University, g.piccolino@lboro.ac.uk

*This is the Accepted Version (prior to copy editing) of an article accepted for publication on 2 April 2019 by Cambridge Review of International Affairs: https://www.tandfonline.com/toc/ccam20/current.

\begin{abstract}
Of all African regional organizations, the West African Economic and Monetary Union (WAEMU) is the one that has most explicitly followed the model of the European Union (EU), emulating key EU institutions and practices. WAEMU's mimicry of the EU is puzzling, considering the economic, political and geographical differences between the European and the West African regional context. This article argues that, in order to understand WAEMU's trajectory, it is necessary to look at two interrelated factors: on the one hand, WAEMU's history of colonial legacies and post-colonial dependence; on the other, WAEMU's drive to mimic institutions seen as embodying standards of modernity and legitimacy. WAEMU's isomorphism has been an outcome of external pressures, but also a response to uncertainty and a result of professionalization. Institutional isomorphism has had a mixed impact on the effectiveness of the organization, helping it to sustain its legitimacy but also stifling endogenous development.
\end{abstract}

Keywords: regional integration, Africa, WAEMU, European Union, institutional sociology

Word count: (excluding abstract): 10278 words 


\section{Introduction}

Many scholars have noted the influence of the European Union (EU) and of its model of integration on the African continent, in particular with respect to the institutional set-up and the vision of integration as a linear succession of stages - from free trade area via customs union to common market (Gibb 2009; Bach 2015; Hartmann 2016).

Given the very different history and structural socio-economic conditions of the African continent, the fact that the European model has continued to be a fundamental reference for many African regional organizations is puzzling (Hartmann 2016, 272; Bach 2015). Nowhere is this puzzle more apparent than by looking at the Union Economique et Monétaire Ouest-Africaine (UEMOA), also known in English as West African Economic and Monetary Union (WAEMU). WAEMU is an organization of eight West African states, all, with the exception of Côte d'Ivoire, considered Least Developed Countries (LDC). WAEMU's member states exist as independent political entities only since the 1960 s. Their economy is largely based on agriculture and natural resources that are exported to the global North. Yet, despite the radically different historical, geographical and economic conditions of the region, WAEMU stands among African regional organizations - and possibly among regional organizations more in general - as the organization that has most faithfully and explicitly drawn inspiration from the EU, an organization of developed industrial economies. Why has WAEMU followed the European model of integration, despite the difficulties that many of its EU-inspired plans and institutions are encountering in a radically different socioeconomic and political regional context?

The purpose of this article is twofold. First, it aims to fill an empirical gap in the study of regionalism by focusing on WAEMU, an organization that has been poorly integrated in comparative regionalism studies but that constitutes an interesting case of relatively advanced and sophisticated regionalism in the African continent. 
Second, the article points to the challenges that existing comparative scholarship faces in accounting for why WAEMU was created as an organization strongly inspired to the European model of integration, and why it is still following in many respects that model today, despite the mixed record of many of its EU-inspired institutions and programmes. While I stress the importance of acknowledging the insight of the sociological institutionalist literature on institutional isomorphism (Meyer and Rowan 1977; DiMaggio and Powell 1983; Pritchett et al 2013) I also argue that it is important to consider how patterns of colonial and post-colonial dependency have shaped the diffusion of regionalism.

These dynamics have interacted. The heritage of colonialism and the current unequal relationships with Europe have encouraged the imitation of foreign models. Transplanting EU 'best practices' is also a strategy that stems from WAEMU's crisis of legitimacy and its need to justify its existence, both vis à vis external donors and the people of the region. However, while institutional isomorphism might help regional organizations to deal with the challenges that they face in the short term, it makes it more difficult to envisage a different model of regionalism, emerging from the local context and from the interaction with local economic and political realities.

My analysis of the WAEMU case can provide useful insights for the study of regional integration in Africa and in post-colonial developing countries more broadly. The International Relations (IR) diffusion literature has up to now insufficiently acknowledged the importance to account for the interaction between historical legacies, post-colonial dynamics and institutional isomorphism. At the same time, Africanist analyses of regionalism tend sometimes to exoticize and essentialize African cases, which are presented as uniquely extraverted and dysfunctional.

The first section introduces WAEMU and the West African region, shows how WAEMU has mimicked the EU in many respects and assesses WAEMU's record of regional integration. The second section reviews the literature on the transfer of regional institutions, 
with particular focus on the African continent. In the third section, I look at how postcolonial dependency and current development challenges encourage institutional isomorphism in the developing world. I then illustrate the mechanisms that fuel isomorphism in the case of WAEMU. In the conclusion, I draw some implications from my analysis for the future of WAEMU and African regionalism in general.

\section{WAEMU: a tropical European Union?}

\section{WAEMU in the West African context}

WAEMU is a regional organization that groups all the former French colonies of West Africa, with the exception of Guinea-Conakry (Benin, Burkina Faso, Côte d'Ivoire, Mali, Niger, Senegal and Togo). Guinea Bissau, the only non-French-speaking member, joined in 1997. WAEMU's mandate focuses on trade and economic integration. According to its treaty, WAEMU's principal aims are the creation of a common regional market, the convergence of the economies of member states through the institution of a multi-lateral surveillance mechanism, the launch of common sectorial policies and the harmonization of legislation regarding fiscal and economic matters (WAEMU 2003, art.4).

Although WAEMU was officially founded in 1994, its roots are much older. In colonial times, the territories that now form the member states of WAEMU were part of the Afrique Occidentale Française (AOF). Even though the AOF disintegrated after decolonization giving way to a series of independent states, French-speaking West African countries, except Guinea-Conakry, which opted out, have continued to share a single currency, the CFA Franc. ${ }^{1}$ The CFA Franc is co-managed by the Banque Centrale des Etats de

\footnotetext{
${ }^{1}$ The acronym is itself an interesting case of post-colonial relabelling. It stood for Colonies françaises d'Afrique ('French colonies of Africa') during colonial time. In 1958, when Charles De Gaulle pushed for the shortlived Franco-African community, the name was turned into Communauté française d'Afrique ('French Community of Africa'). Since the former French colonies have become independent, CFA is taken to mean Communauté Financière Africaine (African Financial Community).
} 
l'Afrique de l'Ouest (BCEAO) and by the French Treasury, pegged first to the French Franc and later to the Euro. In 1972 the countries that adopt the CFA founded the Communauté Economique de l'Afrique de l'Ouest (CEAO), the direct predecessor of WAEMU. WAEMU was subsequently created from the merging of the CEAO and the West African Monetary Union (WAMU) and aimed to rationalize and strengthen its predecessors.

WAEMU is not the only regional organization in West Africa. WAEMU's members are also members of ECOWAS, which groups all states in the region, with the exception of Mauritania, and is recognized as the official West African Regional Economic Community (REC) by the African Union (AU).

Relations between CEAO/WAEMU and ECOWAS have not always been easy. CEAO was initially created as a Francophone counterpower to the Nigeria-led coalition that resulted in the establishment of ECOWAS. On the other hand, non-French speaking ECOWAS members tend to see WAEMU as an obstacle to the integration of the broader West African region (Hartmann 2016). With time, a sort of division of labour between WAEMU and ECOWAS has emerged. Since the 1990s, ECOWAS has developed a peace and security mandate and has established itself as a regional 'watchdog' with regards to violations of democratic rule that could endanger regional peace. In contrast, WAEMU has continued to focus predominantly on socio-economic issues, exploiting the comparative advantage of the monetary union.

The European project of regional integration has inspired both WAEMU and ECOWAS. However, it is in the case of WAEMU that this inspiration is most evident. The next paragraph looks at the influence of the European model of regional integration in Africa, and on WAEMU in particular. 
Many African and European scholars have stressed the importance of the EU as an inspiration for African projects of regional integration (Kufuor, 2006; Sall, 2006; Asante 1985; Bach 2015; Hartmann 2016). On the other end, some recent studies have concluded that African regionalism is a distinctive project, with a logic that is rather different than that of the European project (Fioramonti and Mattheis, 2016; Haastrup, 2013).

A full assessment of the influence of the European project on African regionalism is difficult to make, given the number of diverse regional organizations in Africa. On an overall level, however, it can be said that the influence of the EU is evident in two features of African regionalism. First, the formal, institutional set up of African regional organizations borrows heavily from the European model, with many organizations having councils, commissions and parliaments. Second, African regional organizations share with the EU the objective to create 'an ever-closer union': to build a common regional market, underscored by important elements of political cooperation, rather than limit themselves to a loosely formalized interstate cooperation (Bach 2015; Hartmann 2016). It is worth noticing that this aspiration appears to be typical of the African continent: 'the desired level of regional integration among African regional organizations remain higher than in most other world regions' (Hartmann 2016, 280). In contrast with other regions (for instance East Asian), African intellectuals and practitioners have never advocated a distinctive 'African way' of regionalism, notably one based on intergovernmentalism (Hartmann 2016, 272; see also Bach 2015). Although some African institutions operate de facto in an intergovernmental way, this does not seem the result of a deliberate design rejecting supranationalism in favour of looser forms of cooperation.

Of all African regional organizations, WAEMU is probably the one that has most obviously followed the 'model EU' (Grimm 1999; Sall 2006; Claeys and Sindzingre 2003). Affinities between the EU and WAEMU are particularly evident in the institutional domain. Similarities were already present in CEAO, whose treaty laid down the basis for an 
institutional structure modelled on the European Economic Community, with a Conference of Heads of State and Government, a Council of Ministers, an Executive Secretariat and a Community Tribunal. While there are substantial differences between the CFA and the European monetary union, both of them presuppose the existence of an independent central bank with vast autonomy on matters of monetary policy. The creation of WAEMU has made the parallel with the EU even more evident and reinforced the supranational dimension of the organization. The WAEMU Treaty turned the Secretariat into what has been called 'a pure and simple carbon copy of the European Commission' (Sall 2006, 83). Like the EU Commission, the WAEMU Commission is meant to represent the 'general interest of the Union' (WAEMU 2003, art. 26) ${ }^{2}$ although its powers are less extensive than the ones of the European Commission. The parallels are even more evident between the WAEMU Court of Justice, which replaced CEAO Tribunal, and the EU Court of Justice. The additional protocol to the WAEMU Treaty (WAEMU 1996) confers to the Court the same powers and prerogatives as its EU equivalent. Table 1 summarizes similarities and differences between the EU and WAEMU's institutions.

Institutional similarities are also evident in the type of normative instruments that WAEMU's institutions can adopt. They completely mirror the EU typology: regulations, directives, decisions and recommendations (WAEMU 2003, art. 43). The supranational effect of WAEMU's legislation is stressed by the WAEMU Treaty, which openly states that WAEMU acts 'are applied in all member state regardless of any conflicting national legislation, whether this predates or follows it' (WAEMU 2003, art. 6).

Beyond the institutional domain, the influence of the EU also encompasses some of the normative and policy choices of WAEMU. WAEMU shares with the EU the objective to build a common regional market. The EU and WAEMU's legal regimes regulating the free circulation of goods present numerous parallels (Bougouma 2012). WAEMU also shares with

\footnotetext{
${ }^{2}$ Art. 26 of the consolidated WAEMU treaty (2003): the same phrase is found in art. 17 of the Treaty of the European Union (TEU).
} 
the EU a commitment to the values of economic liberalism and to the importance of macroeconomic stability (Grimm 1999). BCEAO monetary policies follow the European Central Bank and the organization's system of surveillance, regulated by a convergence pact adopted in 1999, is inspired to the criteria of the Maastricht Treaty on fiscal deficit and inflation (Grimm 1999; Claeys and Sindzingre 2003). Other notable similarities between WAEMU and the EU lie in the domain of sectorial policies: following the EU example, WAEMU has created common policies on domains such as education, environment, infrastructures. Like the EU, WAEMU attributes particular importance to its Common Agricultural Policy (Claeys and Sindzingre 2003).

In sum, WAEMU appears to have drawn from the EU both in its institutional form and in its policies. How has the organization fared so far in its efforts to promote regional integration among Francophone countries? Have WAEMU's EU-inspired institutions and programmes helped WAEMU to achieve its desired goals?

\section{WAEMU's record of regional integration.}

Scholars and practitioners have often accused African regional organizations of setting up exaggerated goals that they are then unable to achieve (Gibb 2009; Söderbaum 2004) and of combining 'grand ambitions but little functional co-operation/ integration' (Fioramonti and Mattheis 2016, 12).

On some respects, WAEMU stands as a relatively successful example of regional integration in Africa. The WAEMU custom union is in operation as scheduled since 2000. Under its rules primary goods produced in the region and manufactured goods with at least 30 per cent of local added value are free to circulate (WAEMU 2001a), while exchanges with the rest of the world are regulated by a common tariff, structured around four bands $(0,5,10$ and 20 per cent). Free circulation of persons has also advanced: a national identity card is sufficient to travel in the WAEMU area and specific provisions have been adopted for 
ensuring the right to work in all member states for certain categories of highly-skilled professionals.

In terms of WAEMU's actual success in promoting development by increasing economic exchanges and improving regional economic governance the balance sheet of the organization and of its predecessor CEAO is less positive. Some authors have argued that the CEAO/WAEMU liberalization schemes, coupled with the effect of the monetary union, have been effective in enhancing trade in the current WAEMU area (Carrère 2004). However, intra-regional trade remains low and most of the volume of trade is represented by WAEMU's largest economies - Côte d'Ivoire and Senegal. Moreover, CEAO/WAEMU countries' growth rates in the last thirty years have been lower than the rest of Sub-Saharan Africa (Guillaumont et al 2013).

Regional integration in the WAEMU area is hampered by problems stemming from the weakness of the rule of law and the low institutional capacities of WAEMU and its member states. More than ten years after the launch of the custom union, 'the transport of goods is still hampered by all sorts of regular or occasional issues' and 'common external tariffs are still reproduced in an imperfect manner in the information systems of the States custom offices' (Guillaumont et al 2013, 12). Disregarding WAEMU legislation on the free circulation of persons, custom officials routinely demand fees for people and transport vehicles that pass the borders (WAEMU 2016a). Similarly, the balance sheet of WAEMU's economic surveillance mechanism is mixed. Some criteria, like the imposition of a low annual inflation rate (less than 3 per cent) and of a debt-to-GDP ratio of less than 70 per cent, are effectively implemented. However, criteria related to fiscal revenues are not fulfilled by most member states (WAEMU 2016b), mainly due to poverty, the predominance of the informal economy and a weak fiscal administration.

WAEMU's EU-inspired institutional and legal framework has not always been able to operate as laid out in its treaties and official protocols. The Court of the WAEMU has been 
unable to perform a role equivalent to the EU Court of Justice, because it has received too few referrals. ${ }^{3}$ Other supranational organs have suffered similar difficulties. The WAEMU Commission reflects the lack of financial means and the low administrative capacity of the WAEMU region. With around 400 staff in total, it is roughly the same size as the EU directorate of internal market. ${ }^{4}$ The most important gap between institutional provisions and actual functioning, however, regards the creation of an elected community parliament foreseen by the amended 2003 WAEMU Treaty (WAEMU 2003). The process has been delayed by the turmoil that has engulfed Côte d'Ivoire, which ratified the treaty on the creation of the Parliament only in 2014 (Mareczko 2014). The existence of a parallel plan for an ECOWAS Parliament has also generated polemics (L'Economiste du Faso 2014). The WAEMU's inter-parliamentary committee continues to meet regularly, but cannot exercise the control prerogatives that the WAEMU Treaty attributes to the parliamentary body, such as voting the WAEMU budget and approving a motion of no confidence in the Commission.

The difficulties that WAEMU is experiencing are easy to explain when one looks at the regional economic and institutional context in which the organization operates. Frenchspeaking West Africa is one of the most disadvantaged parts of the world in terms of economic development. Administrative capacity in the region is generally very low, and both corruption and clientelism are widespread (Olivier de Sardan 2004). Most of the conditions that economists consider necessary for custom unions to have sizeable economic benefits, such as high levels of pre-union trade and a large number of economically strong members, are not met by WAEMU. WAEMU's economies show little complementarity: the overall economic structure, based on the export of natural resources and agricultural products towards more industrialized countries, does not facilitate regional integration.

Given Francophone West Africa's structural conditions, which hamper WAEMU's mission, the fact that WAEMU was created as an organization modelled on the EU and that it 
largely remains a 'tropical EU' twenty years after its creation, is puzzling. Indeed, scholars of sub-Saharan Africa have often expressed scepticism about the possibility that EU-inspired institutions can take root in the continent. They argue that the weakness of formal institutions and the existence of important informal dynamics pose a major obstacle to EU-style regional integration in Sub-Saharan Africa (Bach 2015). Because 'the state's legitimacy to define rules and laws for and prescribe them to society is openly challenged and often ignored by large parts of the population', the European way of 'integration through law' becomes 'a very shaky construction' (Grimm 1999, 24). If this is the case however, why did WAEMU choose a highly institutionalized and legalistic model of regional integration in the first place? And why did it aim for a highly integrated common market in a geographical region where the economies exhibit little complementarity? The next section looks at how IR scholars have explained the spread and design of regional institutions and questions the applicability of theories of institutional diffusion to WAEMU.

\section{The diffusion of regional integration}

'Traditional' theories of regional integration saw the development of regional institutions as a process aiming at increasing regional welfare and solve coordination problems. Growing economic interdependence between nations was usually seen as the key force driving regional integration. There are differences between neo-functionalist and intergovernmental theories of integration, but what these approaches have in common is that they 'implicitly or explicitly conceptualize regionalism as driven by the independent decision-making of regional actors responding to causal factors located within or outside the region' (Börzel 2016, 41). These theories would not predict a strong demand for socio-economic integration in Africa in general (Hartmann 2016) or in West Africa in particular, given the relatively low levels of intra-regional trade and the weakness of the private sector in the region. 
The spread of regional institutions in the last fifty years and the rise of constructivist IR approaches focusing on norm diffusion has changed the way regionalism is perceived and studied. Inspiration from outside - in particular the attraction of the 'model EU' - has appeared a significant motivation beyond the creation of new regional organizations. At the same time, an increasing number of regional specialists has started to conduct research on regional institutions in their geographical areas of interest.

In the following paragraphs, I review some of the theoretical literature on the international diffusion of regionalism and I discuss the views of regional specialists about the limits of diffusion in Africa. I aim to show that, while this literature contains valuable insights, it also has limits in explaining the simultaneous popularity of EU-inspired institutions and the difficulties that institutional transfer faces, especially in the context of poor developing countries.

The literature on international diffusion builds on a previous literature on institutional organizations, which stresses that organizations are systems that 'reflect the myths of their institutional environments instead of the demands of their work activities' (Meyer and Rowan 1977, 341). In particular, DiMaggio and Powell's seminal account explored the homogenization of organizational forms and practices. They distinguished between coercive isomorphism, which is the result of 'both formal and informal pressures exercised on organizations by other organizations upon which are dependent', mimetic isomorphism resulting from 'standard responses to uncertainty' and normative isomorphism, which stems from professionalization (DiMaggio and Powell 1983, 150).

While institutional sociologists were studying diffusion among sub-national institutions, predominantly in Western countries, constructivist IR theorists have been interested in unpacking the mechanisms that underline the diffusion of institutions across countries and world regions. The most popular theoretical framework for understanding the spread of the EU model of regional integration is provided by Tanja Börzel and Thomas 
Risse, who outline four potential mechanisms of diffusion (Börzel and Risse 2009; 2012): manipulation of utility calculations, socialization, persuasion and emulation. Börzel and Risse recognize that the spread of the EU model is partly driven by what they call a 'logic of consequentialism': the EU uses incentives and sanctions, providing or withdrawing aid and capacity building assistance, in order to push for integration in other regions. They are however more interested in the other mechanisms, in particular in the 'emulation' mechanism, which is not driven by the EU's own efforts to spread its model. Ther argue that emulation can be driven by normative reasons, e.g. to increase legitimacy (Börzel and Risse 2012, 10).

Empirical accounts confirm Börzel and Risse's argument that the spread of regional institutions is shaped by both the EU's direct engagement and by the EU example (Lenz and Burilkov 2017). However, Börzel and Risse's framework focuses on the mechanisms of diffusion, leaving aside the question of why imported regional institutions do not always work in the way they would be expected to. They also do not address the problem of why European-inspired practices appear to be particularly popular in regions like Francophone West Africa, where the local conditions would seem particularly unfavourable to the development of ambitious and highly institutionalized forms of regionalism.

Regional specialists, such as Fredrik Söderbaum (2004) and Richard Gibb (2009), have tried to account for both the adoption of EU-style institutionalized regionalism in poor areas of the world and its mixed achievements. Söderbaum and Gibb focus on African elites and argue that, because of their subordinate position in the international system, these elites see the formal adoption of foreign models as a way to boost their international legitimacy and obtain foreign 'resources of extraversion', such as development aid and military cooperation. Yet they may not be seriously interested in successfully appropriating those models. The outcome is a syndrome of partial reform, where local actors implement only those components of a foreign-sponsored agenda that do not endanger their interests and their entrenched governance practices, voiding it of its substance. Both Gibb and Söderbaum 
strongly insist on the symbolic and ceremonial dimension of regionalism and argue that 'regime-boosting regionalism' (Söderbaum 2004) reinforces neo-patrimonial regimes since 'belonging to a formal, states structured, regional organization is interpreted as an important symbol of the virility of sovereignty, as regional integration is based on and presupposes formal state sovereignty' (Gibb 2009, 716).

Gibb and Soderbaum's perspective has a lot in common with that of Etel Solingen, who argues that some regional institutions, like the Arab League, have been 'designed to fall', because the leaders who created them where more interested in using the organization as a tool for shielding their sovereignty than in advancing substantive regional goals (Solingen 2008). While this perspective offers important insights, it has also several limits. The picture that it paints of African regionalism is static and exaggeratedly bleak and does not distinguish between African organizations that have been partially successful (such as WAEMU or ECOWAS) and African organizations that have been outright failures (for instance, the Communauté économique des Pays des Grands Lacs (CEPGL) or the Arab Maghreb Union (AMU)). Looking at WAEMU, although some of its institutions have remained dysfunctional, it is difficult to argue that the organization as a whole was 'designed to fail' (Hartmann 2016). In addition, Gibb and Söderbaum depict African regional organizations as an emanation of their member states, neglecting increasing evidence that the secretariats and commissions of African organizations are assuming an active role in shaping the agenda of their institutions (Hartmann 2016, 277).

Gibb and Soderbaum however make an important point when they acknowledge the importance that the relationship of dependence between Africa and Europe plays in the diffusion of regionalism. They observe that, although EU-Africa cooperation is officially built around the notion of 'partnership', relations between Europe and Africa continue to be shaped by the huge difference in economic and political power between the two continents (Gibb 2009, 702). 
A way to acknowledge the insights of both theories of international norm diffusions and of Africanist scholarship while overcoming their limitations is to take back the insights of sociological institutionalism and understand how institutional isomorphism works in a context shaped by post-colonial dependency.

\section{Institutional isomorphism in a post-colonial context}

The diffusion of foreign institutional models to sub-Saharan Africa goes beyond the debate on regionalism. The spread of institutionalized regionalism should be placed in the historical context and seen as just a chapter in a history marked by many attempts at transferring foreign models of political and economic governance to the continent (Gibb 2009, 702). Most West African states, including all WAEMU members, have been created as a result of colonialism and are still largely modelled on their colonial antecedents. After the end of colonialism, they have remained economically dependent on industrialized countries for the export of their primary goods, for development assistance and, often, for security. In the post-independence decades, they have continued to be the object of many foreign intrusions carried out in the name of development, structural adjustment, and post-conflict reconstruction. External interventions have probably contributed to the survival of poor and weak states but have also perpetuated long standing deficits in terms of legitimacy and accountability. Pierre Englebert argues that the contemporary state in sub-Saharan Africa 'remains exogenous: European, not African, and set up against African societies rather than having evolved out of the relationships of groups and individuals in societies' (Englebert 1997, 767). Similarly, for Michael Moore "Southern" states have been created and political authority shaped through interactions with the wealthier Northern countries in the context of global economic and

political systems' and their governance difficulties stem 'from what might be termed a "disconnect" between states and citizens' (Moore 2000, 387). 
Some African and European observers lament a similar lack of embeddedness and disconnect from local civil societies when it comes to African regional organizations. Adekeye Adebajo remarks that, while the force of the European project of regional integration laid, until recently, in the fact of being 'grounded in the politics, economics, and societies of the continent' (Adebajo 2012, 78), the African project of regional integration 'became delinked from resources and concrete interests, often degenerating into meaningless declarations and empty pledges' (Adebajo 2012, 78). Christopher Hartmann observes that 'the most puzzling aspect of African regionalism appears to be the continuing gap between the ambition, innovation and multiplication of state-led regionalism, on the one hand, and the lack of broader social engagement with the projects, on the other' (Hartmann 2016, 272).

Constructivist IR scholars rarely discuss the impact of history - in particular colonial history - on international diffusion. However, the theoretical framework and the categories developed by the literature on institutional isomorphism (Meyer and Rowan 1977; DiMaggio and Powell 1983) can be productively applied to the colonial and post-colonial contest (Claeyé and Jackson 2012; Pritchett, Woolcock and Andrews 2013), showing how historical legacies and contemporary global inequalities are shaping institutional diffusion and institutional mimicry.

I consider here five theoretical mechanisms, which can be used to analyze institutional convergence in a post-colonial context: coercion, manipulation of utility calculation, competition, normative isomorphism and mimetic isomorphism. My mechanisms are partly based on DiMaggio and Powell (1983) but I introduce two changes to their framework. First, following Börzel and Risse (2009), ${ }^{5}$ I distinguish between coercion in the sense of physical, violent imposition, and the less direct pressures resulting from the provision or withdrawal of aid and other material resources (manipulation of utility calculation). Second, I introduce the mechanism of competition which, as Jens Beckert notices, was 'deliberately left out' by

\footnotetext{
${ }^{5}$ Interestingly, Börzel and Risse mention coercion as a potential theoretical mechanism but argue that it has not played a role in the diffusion of EU-inspired regional institutions.
} 
DiMaggio and Powell because 'they were aiming for a theoretical conceptualization of isomorphism that would provide an alternative to Max Weber's emphasis on the role of competitive market pressures' (Beckert 2010, 160).

Empirically, it might not always be possible to establish a rigid distinction between different diffusion mechanisms. The spread of economic liberalization and privatization reforms, a case much discussed by the diffusion literature, for instance, can be seen as a rational process of lesson-drawing driven by policy makers that have seen these reforms working in other contexts, a competition to capture resources from donors and international financial institutions or the result of a normative pressure to adopt a 'proper' economic neoliberal model. However, the mechanisms outlined by the literature can be used as ideal types that provide useful insights over the processes of diffusion.

The experience of colonialism can be considered in itself a process involving a considerable degree of coercive isomorphism (Bhabha 1984; Claeyé and Jackson 2012): postcolonial theorists such as Homi K. Bhabha have talked of an actual process of 'colonial mimicry' $(1984,126)$. Colonial powers transferred aspects of their own administrative and bureaucratic structures to developing countries. Diffusion was however selective and shaped by the interests of the colonizers. Colonial subjects were encouraged to mimic the coloniser and seek 'assimilation', but not to an extent that would have put them on the same level as the colonizers (Bhabha 1984, 126). While colonial domination as such has today ceased, path dependency has at least in part 'locked in' colonially-derived institutions in developing countries (Acemoglu, Johnson and Robinson 2001).

Although in the post-colonial context the direct imposition of foreign models has ceased, the manipulation of utility calculations through incentives and sanctions continue to fuel diffusion (Börzel and Risse 2009; 2012; Lenz and Burilkov 2017). Developing countries are often constrained in their choices by the intrusive interventions of international development partners. Conditionalities that accompany official development aid and loans 
often amount to efforts to transfer specific economic and political institutional frameworks and policies, from the Washington consensus, to democratic elections to gender rights. Institutions built by developing countries also compete between themselves for aid and other forms of foreign assistance. This encourages diffusion further through the mechanism of competition (Börzel and Risse 2012, Gilardi 2012), pushing these institutions to adopt reforms that they believe would facilitate their relationships with donors and industrialized countries.

Diffusion in the post-colonial context, however, also stems from mimetic isomorphism - defined by DiMaggio and Powell as 'resulting from standard responses to uncertainty' (1983, 150). The decision to keep institutions created by colonial powers - for instance state borders designed by colonialists - and to model state bureaucracies from the former colonial master can be seen as a way to deal with the context of uncertainty that former colonies faced with the attainment of independence. Uncertainty also stems from the enormous pressures that the bureaucracies of developing countries experience to demonstrate that they are working towards ill-defined goals such as 'development' or 'good governance' (Pritchett et al 2013), International and local decision-makers 'seek to modernize institutions by intensifying a process of reform via the importing of methods and designs deemed effective elsewhere' (Pritchett et al 2013, 4), also because it is unclear which other methods could work.

Both coercive and mimetic isomorphism interact with normative isomorphism. Organizations that provide aid and loans to institutions in developing countries typically also bring all kind of 'expertise' and 'capacity building' with them. Local 'epistemic communities' with connections to international actors play a major role in the transfer of norms and ideas perceived as embodying 'professionalism' from the global north to the global south (Lenz 2013). With regard to regional institutions, for instance, the United Nations Economic Commission for Africa (UNECA) played a major role in the spread of EU-style institutions in Africa (Asante 1985). 
Normative pressures also come to play a role through a different mechanism. As previously noticed, African postcolonial institutions suffer of a legitimacy deficit because of their colonial origin and lack of social embeddedness (Englebert 2000). This legitimacy deficit is intensified by the unrealistic expectations placed on them after independence and their subsequent failures to satisfy them. Paradoxically, the reaction of post-colonial institutions to this legitimacy crisis is often to conform even more closely to the Western institutions they have been modelled from. The post-colonial condition encourages former colonial subjects to devalue their own tradition and embrace as the 'proper' and 'desirable' ones the 'habits, assumptions, institutions and values' of the former colonizer (Claeyé and Jackson 2012, 615). Institutions and norms associated with industrialized countries are perceived as successful and legitimate models of organizations, embodying desirable standards of modernity (Jetschke 2009, 409; Pritchett et al 2013).

What are the consequences of isomorphism in a post-colonial context? The literature stresses that importing the form of successful organizations is no guarantee of importing their actual capabilities (Pritchett et al. 2013, 7) and that the preoccupation for legitimacy can trump a preoccupation with efficiency (Jetschke 2009, 409; Pritchett et al 2013). Pritchett, Woolcock and Andrews, for instance, argue that material incentives and symbolic legitimacy are often awarded not in response to demonstrated accomplishment but of formal compliance with internationally approved rules and practices, creating a vicious circle (Pritchett et al $2013,2)$. They also contend that the import of international 'best practices' can create a situation of 'pre-mature load bearing in which stresses exceed capability' (Pritchett et al, 2013, 9). Institutions tend to enlarge their mandate to new tasks or to set new ambitious goals, which they are in the end not able to achieve.

The argument that the quest for externally-driven legitimacy has trumped effectiveness partly echoes Gibb and Söderbaum's view, which posits that African regional organizations have often been more effective in boosting the international standing of their members than in 
addressing real-existing problems. However, for Gibb and Söderbaum the culprit is the bad faith of regional leaders, while institutional sociology acknowledges that mimicry can be a rational, although not always effective, response to a situation of uncertainty. The outcome of mimicry process is also not so rigidly determined. The interests and preoccupations of local actors can in some case undermine foreign imported policies and institutions. In other cases, however, local actors, including state elites but also regional bureaucrats, or civil society organizations, can successfully appropriate external models, reinventing and readapting them in a way that respond to local concerns (Acharya 1997; Alter 2013).

Anja Jetschke (2009)'s analysis of isomorphic mimicry in the context of ASEAN is particularly relevant to the analysis of African regionalism and to the discussion about the consequences of mimicry. She highlights that, contrarily to the previous emphasis on ASEAN as an alternative model of integration, ASEAN has tended to mimic the EU selectively (Jetschke 2009). As in sub-Saharan Africa, the mimicry of the EU model by ASEAN has been in part motivated by the desire to attract foreign resources. The EU model has been imported 'primarily in nomenclature and labelling' rather than in 'substance' (Jetschke 2009, 418) and institutional isomorphism has resulted in the launch of '"oversized" projects' and in a 'record of inefficiency and implementation failures' (Jetschke 2009, 409). The case of ASEAN, however, also proves that inefficiencies in some areas can coexist with success in other areas: the organization remains widely credited for creating a sense of community and mitigating inter-state tensions in South East Asia (Acharya 2014).

In the next section, I analyze institutional isomorphism in WAEMU, highlighting how different mechanisms at different stages of its evolution have pushed WAEMU to borrow from the European model. In the first paragraph, I look at how external actors - France and the EEC/EU - have shaped from the outside WAEMU's regionalism through coercion and manipulation of utility calculations. However, isomorphism within WAEMU has not always been driven by direct external involvement. In the second paragraph, I look at the regional and 
institutional dynamics that are pushing the organization to take inspiration from external models seen as legitimate and effective in order to justify its existence, assessing the impact of mimetic and normative isomorphism.

\section{WAEMU and the power of institutional isomorphism}

\section{Post-colonial dynamics and aid dependency}

WAEMU's evolution has been shaped from the outside by coercive isomorphism and the manipulation of utility calculation. Historical and material constraints stemming from the heritage of colonialism and post-colonial dependency on Europe have constrained WAEMU's choices. WAEMU leaders have been under pressure from their international partners particularly France, the former colonial power, and the European Economic Community (EEC)/EU itself - to adopt Europe-inspired institutions while building their regional project.

Through the creation of the CFA monetary union, which was established during colonial time through coercion, France was the real initiator of cooperation between Frenchspeaking West African countries. Although the CFA zone was initially a heritage of colonial policy, and not an example of the diffusion of a European model of regionalism, the line blurred as France subsequently pushed the EEC to support regional cooperation in the West African CFA zone. While both European and African agency played a role in perpetuating the existence of a 'CFA bloc', the monetary union also created a situation of post-colonial path dependency, easing cooperation within Francophone West Africa and making more difficult cooperation, in particular in the economic and monetary domain, through the Francophone/Anglophone divide.

The creation of CEAO should be placed in a historical period in which Francophone African countries were formally decolonized but in practice heavily dependent on France for 
aid, trade and even security, hence vulnerable to the manipulation of utility calculations. CEAO was created as an alternative organization to a Nigeria-dominated ECOWAS and to establish a fait accompli in Francophone West Africa before Great Britain's entry into the EEC (Asante 1985, 76). While Francophone West African elites (particularly Ivorian president Félix Houphouët-Boigny) also pushed for the establishment of the new organization, French and European elites had a large role in shaping it. Stressing the continuity between the colonial and the post-colonial era, Jacques David, an EEC officer and former French colonial administrator, played a key role in drafting the CEAO treaty (Asante 1985, 83). The CEAO Treaty thus laid down the basis for an institutional structure modelled on the EEC.

Similar dynamics have underscored the creation of WAEMU (Grimm 1999; Claeys and Sindzingre 2003; Sall 2006). The WAEMU Treaty was concluded in what was a period of economic crisis for French speaking West Africa and coincided with the first devaluation of the CFA Franc. Although the decision to transform CEAO into WAEMU was a response to regional problems, the decision to address these problems by strengthening supranationalism in the design of WAEMU institutions and reinforcing monetary governance was highly driven by the EU direct involvement. The organization was established a relatively short time after the adoption of the Maastricht Treaty in Europe, and the WAEMU Treaty was inspired by parallel developments in Europe. Like David twenty years before, EEC/EU officials, particularly the General Secretary of the European Commission Emile Noël, were directly involved in the drafting of the WAEMU founding treaty (Grimm 1999, 1). Again, some of the choices of the new organization were shaped the pattern of post-colonial path dependency created by the monetary union. Because the CFA Franc continued to be pegged to the French Franc and later to the Euro, WAEMU was obliged to adopt macroeconomic rules inspired by those established by the EU growth and stability pact.

The manipulation of utility calculations is also evident in the role of European aid. In addition to providing technical advice, the EEC/EU has spent a significant amount of aid in 
support of regional cooperation among French-speaking West African states. Former French African colonies started to receive inter-regional aid in 1963, although CEAO was not a major recipient of European funding (Coste and Egg 1998, 176). With the adoption of the WAEMU treaty, the EU scaled up its support. In 1998, more than two thirds of WAEMU's budget was funded by the EU (Grimm 1999, 16). Overall, under the seventh and eighth European Development Funds (EDF), the EU financed three Programmes to support regional integration among WAEMU countries, amounting to EUR 94.4 million. ${ }^{6}$ This money was spent to support the creation of the new institutions, the launch of the custom union and the new multilateral surveillance system, reinforcing the convergence between WAEMU and the EU.

Since 2000, with the adoption of the Cotonou convention, the EU has paid increasing attention to ECOWAS and to the implementation of its peace and security mandate. Since the tenth EDF (2007-2013) there is no separate financial envelope anymore for WAEMU, but the organization has continued to be included in all the Regional Indicative Programmes. The overall financing of EU inter-regional cooperation with West Africa has skyrocketed, passing from EUR 235 million for the ninth EDF (2002-2007), to EUR 597 million for the tenth EDF, to EUR 1,150 million for the current, eleventh, EDF (2014-2020). Although the 2014-2020 programme formally designates peace and stability as its first priority, most of its resources continue to be earmarked for domains where WAEMU is actively involved: about 50 per cent of funding is dedicated to economic and trade integration and 25 per cent to natural resources management (European Commission 2014). The EU thus remains a key partner for WAEMU.

\section{Mimetic and normative isomorphism}

WAEMU's dependence on external aid only partly explains why WAEMU continues to stick to the EU model. The agency of West African political leaders and of WAEMU's officials, 
and the way it fuelled isomorphism through the mimetic and normative mechanism, should also be considered.

When cooperation within the Francophone block started, mimetic isomorphism was a response to a situation of uncertainty: the EEC was offering its assistance and CEAO had little other successful models of integration to look at. WAEMU is facing again today a climate of uncertainty, where WAEMU's tendency to copy EU institutions and practices should be seen as WAEMU's response to an environment where its legitimacy and the rationale for its existence are increasingly questioned. WAEMU and its predecessor CEAO have been historically accused to reinforce the Francophone/Anglophone divide and to be an obstacle to deeper integration within the whole West Africa region. Since the 1990s, WAEMU's regional rival ECOWAS has showed a renewed dynamism, which threatens WAEMU's standing. WAEMU is increasingly seen as a 'historical accident', destined to dissolve itself within the larger West African region as integration within ECOWAS advances.

One of the main reasons why WAEMU persists as a separate organization is the path dependency generated by the existence of the CFA monetary union, coupled with ECOWAS inability to advance its own monetary integration agenda. However, the CFA Franc is increasingly contested by intellectuals and activists. On the one hand, some African and European economists argue that the regime of fixed parity with the Euro and the antiinflationist policies of the BCEAO have discouraged pro-growth policies and damaged the economies of the region (Nubukpo et al 2016). On the other hand, Panafricanist activists contend that the currency is a symbol of neo-colonial meddling and an offense to the independence and sovereignty of African countries (Pigeaud and Sylla 2018).

WAEMU's officials are thus under pressure to show to the public that WAEMU still has a role to play alongside ECOWAS and a mission that goes beyond the post-colonial legacy of the CFA union. Competition with ECOWAS for EU aid plays a role. Although France continues to lobby the EU for continuous support to WAEMU, some EU officials 
share the view that European aid should be primarily directed to ECOWAS. ${ }^{7}$ At the same time, the mechanism of mimetic isomorphism encourages regional bureaucrats to react to a situation of uncertainty by copying the external model that is more familiar to them, which is the European one. Normative isomorphism is also at play. WAEMU's current justification for existence is that it represents a group of countries that are more advanced on the road of market integration than the rest of ECOWAS members and can thus be an example for the rest of the region. It is important for WAEMU to reinforce its image of an organization conforming to an 'appropriate model' of regional integration. Regional bureaucrats have been socialized in an environment where European institutions are seen as the 'gold standard' of professionalization for regional institutions. Many WAEMU staff are open about the fact that the EU represents an important reference point for them, despite its limitations. The EU is admired for what is seen as its contribution to peace $^{8}$ and to a socially sustainable model of economic development. ${ }^{9}$ WAEMU officials participate regularly in study tours of Brussels and have regular contact with EU officials. They are also very knowledgeable about specific EU programmes that they consider exemplify best practice, such as the Erasmus programme ${ }^{10}$ and the Structural Funds. ${ }^{11}$

As noticed previously, parallelism between the EU and WAEMU are not limited to the institutional design of the organizations laid out in their Treaties, but extend also to some of the policies that the two organizations have adopted. Since 2000, WAEMU has produced a series of new initiatives clearly inspired by the EU model, in many cases under the impulse of its own Commission, albeit with some support from external donors. In 2001, the Conference of Heads of States and government adopted the Additional Protocol on WAEMU sectoral

7. Interview, Official of EU delegation to Burkina Faso and WAEMU, Ouagadougou, 11 October 2013.

8. Interview, official of WAEMU Commission C, 16 October 2013, Ouagadougou.

9. Interview, official of WAEMU Commission D, 11 October 2013, Ouagadougou.

10. Interview, official of WAEMU Commission C, 11 October 2013, Ouagadougou; Interview, official of WAEMU Commission E, 11 October 2013, Ouagadougou.

11. Interview, official of WAEMU Commission A, 16 October 2013, Ouagadougou; Interview, official of WAEMU Commission F, 10 October 2013, Ouagadougou. 
policies (WAEMU 2001b) and the Additional act adopting the agricultural policy of WAEMU (WAEMU 2001c). These sectoral policies have been operationalized, from 2006 onwards, through two Regional Economic Programmes (PER I and PER II), designed by the Commission and jointly implemented by the organization and its member states. It is openly acknowledged that, through the PERs, WAEMU wanted to do a 'job in the EU structural funds style'. ${ }^{12}$ The PERs have included many small-scale development projects, such as the drilling of village wells or the Erasmus-style financing of about 40 scholarships for student mobility. ${ }^{13}$ WAEMU also created, in 2011, a consultative Council of Local Authorities in charge of contributing to the implementation of further actions, including a cross-border cooperation programme that closely resembles the EU European Territorial Cooperation (Interreg).

WAEMU's case shows how it is difficult to draw a clear line between a conscious, rational logic of lesson-learning and a symbolic quest for legitimacy and recognition. WAEMU officials complain that the work of the organization is insufficiently known to the average West African citizen. ${ }^{14}$ The PERs thus aimed to make WAEMU better known, bringing regional integration closer to the people. ${ }^{15}$ However, consistent with what studies of isomorphic mimicry in the context of governance assistance predict (Moore 2001; Pritchett et al 2013) the result of WAEMU's efforts has been to overburden itself and put the already modest human and financial resources of the organization under stress. ${ }^{16}$

It is interesting to notice that WAEMU's tendency to overstretch its capacities, as well as similar problems faced by its partner-rival ECOWAS, are increasingly acknowledged by European donors themselves. EU officials routinely lament the low 'absorption capacities' of West African regional organizations when it comes to managing external aid (European Court

12. Interview, Official of EU member state embassy, Ouagadougou, 18 October 2013.

13. Interview, official of WAEMU Commission D, 11 October 2013, Ouagadougou.

14. Interview, official of WAEMU Commission A, 16 October 2013, Ouagadougou.

15. Interview, Official of EU member state embassy, Ouagadougou, 18 October 2013.

16. Interview, Official of EU member state embassy, 18 October 2013, Ouagadougou; Interview, African

Development Bank official, 17 October 2013, Ouagadougou. 
of Auditors 2009). However, the EU efforts to address the problem have not been very effective and might even have further strengthened the drive towards mimetic and normative mimicry without substantial institutional reinforcement. The EU has augmented aid allocation and dedicates increasing amounts of aid to 'building the capacities' of West African organizations, through dedicated activities such as seminars and training courses (European Commission, 2014). Both interviews with African officials and previous research suggests that such measures might reinforce dependency from the outside and not tackle the true reasons behind insufficient aid absorption ${ }^{17}$ (Pritchett et al 2013). Indeed, WAEMU's officials' participation in EU-sponsored capacity building might push these bureaucrats to see themselves as professionals of regional integration, reinforcing normative isomorphism, without necessarily strengthening WAEMU's functionality.

\section{Conclusion: the future of WAEMU}

This article has looked at the historical trajectory and at the current pressures that have led WAEMU, an organization of extremely poor post-colonial states, to become a 'poster child' for the adoption of EU-inspired norms and practices in sub-Saharan Africa. Colonialism has left Francophone West Africa with a legacy of extraverted institutions; post-colonial dynamics and lack of material resources have fuelled dependence on European aid; and, in an impoverished and marginalized region, the pressure to adopt models that are perceived as embodying international standards of success and legitimacy is particularly high.

While WAEMU is to some extent an exceptional example of an African regional organization, due to its origins in the colonial monetary union, the massive external support that it has received from the EU and its relatively high levels of integration, the same mechanisms that have fuelled isomorphic mimicry in the case of WAEMU can be seen at play also in other organizations. 
In a similar way as the rivalry between WAEMU and ECOWAS and their competition for external aid has encouraged the adoption of EU-derived norms and institutions by WAEMU, the EU's threat to shift support to other regional organizations has fuelled institutional reform in the Southern African Development Community (SADC). Lenz and Burilkov (2017) attribute to the EU's involvement the strengthening of the secretariat and the establishment of a EU-style regional court of justice.

In a subtler way, although ECOWAS has very different origins than WAEMU, it also ended up selectively mimicking the EU and its neighbour/rival WAEMU. ${ }^{18}$ Some of ECOWAS EU-inspired institutions, such as the Parliament and the Court of Justice, have never worked in the way ECOWAS' revised treaty envisaged. In an interesting twist, under pressure from local human rights organizations, the ECOWAS Court of Justice has started to statue about human rights issues (Alter et al 2013) - an example that shows how imported institutions can be reinvented to respond to local concerns.

Although the actual functioning of the AU is rather different than the EU (Haastrup 2013) the founders of the AU still felt compelled to adopt the word 'union' in the name, model their flag after the EU flag and create an institutional structure that is reminiscent of the EU (Fioramonti and Mattheis 2016). These similarities are 'a "bumper sticker", a sort of visible certification or quality control, which has allowed the AU and its RECs to become privileged partners of the EU' (Fioramonti and Mattheis 2016, 686). In other words, these similarities are driven by the concern with external legitimacy. Still very dependent from the outside, African regional organizations and the states that created them feel the need to demonstrate that they are following 'proper' models of regionalism.

Indeed, if WAEMU is to some extent unique, it is not because of its tendency to mimic the EU, but because of its success in doing it, going beyond superficial imitation. However, its case shows that, even when EU-style regionalism is 'successful' in the sense of meeting 
targets such as the creation of a custom union, it is not necessarily successful in solving regional problems - such as the low level of formal intra-regional trade and the general lack of economic development. Isomorphic mimicry in the African continent has led in some cases to the triumph of form over functionality and in others to institutional overburdening. As previously remarked, African regional projects struggle to reconnect with their societies (Adebajo 2012; Hartmann 2016), and organizations such as WAEMU tend to expand their mission to tasks that they are insufficiently equipped to carry out, rather than focusing on what they can do best.

Both policy-makers and academics have often taken for granted that the diffusion of regionalism is a positive development, and that the responsibility for failure lies within developing countries that have not implemented regional agreements 'correctly'. However, especially for poor countries, the establishment of trade agreements and regional institutions is valuable if it does not become an end in itself, but rather a means to advance developmental goals. In sub-Saharan Africa, the tendency to focus on symbolic milestones, rather than substantial achievements, has been encouraged by international partners, including the EU itself.

The crisis of the Eurozone and Brexit, coupled with the difficult negotiations behind the Economic Partnership Agreements between African regional organizations and the EU, are however gradually impacting the attractiveness of the model EU in Africa. The EU's lessons for African development, which include 'the affirmation of the benefits of competition, trade openness and fiscal adjustment as the only routes towards growth' (Sindzingre, 2016, 82) are increasingly questioned. ${ }^{19}$

WAEMU is now at a crossroad. The organization is accused of being increasingly obsolete, and non-Francophone West African leaders would arguably be happy to see it dissolving within the larger ECOWAS. However, given the role of the CFA union and 
WAEMU's record of relatively advanced integration, is it unlikely that the organization will be dismantled in the short term. If it wants to play a positive role in the region, however, WAEMU needs to reinvent itself by adapting its core mandate to local needs. This means, for instance, clarifying the division of labour with ECOWAS, avoiding duplications of efforts. The debate on the monetary union should focus less on its history, and more on its advantages and disadvantages from a developmental perspective. If the CFA union is preserved, this needs to be done in a way that breaks with the CFA colonial symbology and avoids the automatic adoption of macro-economic surveillance criteria copied by industrialized countries. 


\section{Bibliography}

Acemoglu, Daron, Simon Johnson, and James A. Robinson (2001), 'The colonial origins of comparative development: An empirical investigation'. American economic review 91:5,13691401.

Acharya, Amitav (1997) 'Ideas, identity, and institution-building: from the "ASEAN Way" to the “Asia-Pacific Way”?' The Pacific Review, 10:3, 319-346.

Acharya, Amitav (2014). Constructing a security community in Southeast Asia: ASEAN and the problem of regional order, 3rd edition (Abingdon: Routledge).

Adebajo, Adedeje (2012) 'Paradise lost and found: the African Union and the European Union' in Adedeje Adebajo and Kaye Whiteman (eds) The EU and Africa: From Eurafrique to Afro-Europa (London: Hurst), 45-82.

Alter, Karen J, Laurence R Helfer, and Jacqueline R McAllister (2013) ‘A new international human rights court for West Africa: the ECOWAS Community Court of Justice'. American Journal of International Law, 107:4, 737-779.

Asante, SKB (1985) 'ECOWAS/CEAO: conflict and cooperation in West Africa'. In Ralph I.

Onwuka and Amadu Sesay (eds) The future of regionalism in Africa (London: Macmillan), 74-95.

Bach, Daniel (2015) Regionalism in Africa: genealogies, institutions and trans-state networks (Abingdon; Routledge).

Bhabha, Homi (1984), Of mimicry and man: the ambivalence of colonial discourse, October $28,125-133$.

Börzel, Tanja A. (2016) 'Theorizing regionalism' in Tanja A. Börzel and Thomas Risse (eds) The Oxford handbook of comparative regionalism (Oxford: Oxford University Press), 41-63. 
Börzel, Tanja A. and Thomas Risse (2009) 'Diffusing (Inter-) regionalism. The EU as a model of regional integration', Working Paper 7, The Transformative Power of Europe series, Free University of Berlin, Berlin.

Börzel, Tanja A., and Thomas Risse (2012). "From Europeanisation to diffusion: introduction." West European Politics 35:1, 1-19.

Bougouma, Ousmane (2012), 'Free movement of goods in WAEMU and the European Union community law: a comparative study from the perspective of trade' in Elias T. Ayuk and Samuel T. Kaboré (eds), Wealth through Integration: Regional Integration and PovertyReduction Strategies in West Africa (Ottawa: Springer), 147-170.

Carrère, Cèline (2004) 'African regional agreements: Impact on trade with or without currency unions'. Journal of African Economies, 13:2, 199-239.

Claeyé, Frederik, and Terence Jackson (2012) 'The iron cage re-revisited: institutional isomorphism in non-profit organisations in South Africa.' Journal of International Development 24:5, 602-622.

Claeys, Anne-Sophie, and Alice Sindzingre (2003) 'Regional integration as a transfer of rules: the case of the relationship between the European Union and the West African Economic and Monetary Union (WAEMU)', 10-12 September, Development Studies Association Annual Conference, University of Strathclyde, Glasgow.

Coste, Jérome, and Johnny Egg (1998) ‘L’appui de l’Union Européenne à l'intégration régionale: une (double) projection trompeuse? Le cas de l'Afrique de l'Ouest' in Groupement d'Intérêt Scientifique pour l'Étude de la Mondialisation et du Développement (GEMDEV) (ed), La Convention de Lomé en questions: les relations entre les pays d'Afrique, des Caraïbes et du Pacifique (ACP) et l'Union Européenne après l'an 2000 (Paris: Karthala), 168-185. 
DiMaggio, Paul, and Walter W Powell (1983) 'The iron cage revisited: collective rationality and institutional isomorphism in organizational fields'. American Sociological Review, 48:2, $147-160$.

Englebert, Pierre (1997), 'The contemporary African state: neither African nor state', Third World Quarterly, 18:4, 767-775.

European Commission (2014) 'European Union - West Africa. Regional Indicative Programme 2014-2020', $<$ https $\% 3$ A $\% 2 F \% 2 F e c . e u r o p a . e u \% 2 F e u r o p e a i d \% 2 F s i t e s \% 2 F d e v c o \% 2 F f i l e s \% 2 F e e a s-2015-$ rip-westafrica_en.pdf\&ei=2XTgVcLYJMm_aJzRotAN\&usg=AFQjCNHTpBUSPvaZtYVEp8x4TXs EgYYAQ\&sig2=jg0oag4PjCcfjdOj5P_Pew>, accessed 28 August 2015.

European Court of Auditors (2009) EDF Support for Regional Economic Integration in East Africa and West Africa, Special Report 19, $<$ http://eca.europa.eu/portal/pls/portal/docs/1/8030724.PDF>, accessed 26 July 2013. Fioramonti, Lorenzo and Frank Mattheis (2016) 'Is Africa really following Europe? an integrated framework for comparative regionalism', Journal of Common Market Studies, 54:3, 674-690.

Gibb, Richard (2009) 'Regional integration and Africa's development trajectory: metatheories, expectations and reality', Third World Quarterly, 30: 4, 701-721.

Gilardi, Fabrizio (2012) 'Transnational diffusion: Norms, ideas, and policies', in Walter Carlsnaes, Thomas Risse and Beth A. Simmons (eds) Handbook of international relations, (Sage: London), 453-477.

Grimm, Sven (1999) 'Institutional change in the West African Economic and Monetary Union (WAEMU) since 1994: a fresh start after the devaluation shock?', Africa Spectrum, 34:1, 5-32. 
Guillaumont, Patrick, Anne-Marie Geourjon, Samuel Guerineau, and Sylviane Guillaumont (2013) Intégration régionale pour le développement en Zone franc (Fondation pour l'Etude et la Recherche sur le Développement International, Economica: Paris).

Hartmann, Christof (2016) 'Sub-Saharan Africa' in Tanja A Börzel and Thomas Risse (eds) The Oxford handbook of comparative regionalism (Oxford: Oxford University Press), 271Jetschke, Anja (2009) 'Institutionalizing ASEAN: celebrating europe through network governance', Cambridge Review of International Affairs, 22:3, 407-426.

Lenz, Tobias (2013) 'EU normative power and regionalism: ideational diffusion and its limits', Cooperation and Conflict, 48:2, 211-228.

L'Economiste du Faso (2014), 'UEMOA : La crise des 20 ans', $<$ https://www.leconomistedufaso.bf/2016/01/25/uemoa-la-crise-des-20-ans/>, accessed on 26 December 2018.

Meyer, John W and Brian Rowan (1977) 'Institutionalized organizations: formal structure as myth and ceremony'. American Journal of Sociology, 83:2, 340-363.

Moore, Mike (2001) 'Political underdevelopment: what causes "bad governance", Public Management Review, 3: 3, 385-418.

Nubukpo, Kako, Martial Ze Belinga, Bruno Tinel and Demba Moussa Dembélé (2016), Sortir l'Afrique de la servitude monétaire: à qui profite le franc CFA? (Paris: La Dispute).

Olivier de Sardan, Jean-Pierre (2004) 'État, Bureaucratie et Gouvernance en Afrique de 1'Ouest Francophone', Politique Africaine, 4, 139-162.

Pigeaud, Fanny, and Ndongo Samba Sylla (2018), L'arme invisible de la Françafrique. Une histoire du franc CFA (Paris: La Découverte).

Pritchett, Lant, Michael Woolcock and Matt Andrews (2013) 'Looking like a state: techniques of persistent failure in state capability for implementation', Journal of Development Studies, 49:1, 1-18. 
Sall, Alioune (2006) Les mutations de l'intégration des états en Afrique de l'Ouest: une approche institutionnelle (Paris: L'Harmattan).

Sindzingre, Alice Nicole (2016) 'From an eroding model to questioned trade relationships: the European Union and Sub-Saharan Africa', Insight on Africa, 8:2, 81-95.

Söderbaum, Fredrik (2004) 'Modes of regional governance in Africa: neoliberalism, sovereignty boosting, and shadow networks', Global Governance, 10:4, 419-436.

Solingen, Etel (2008). 'The genesis, design and effects of regional institutions: lessons from East Asia and the Middle East', International Studies Quarterly, 52:2, 261-294.

West African Economic and Monetary Union (WAEMU) [Union Economique et Monétaire Ouest Africaine] (1996) Protocole Additionnel N.1 relatif aux Organes de contrôle de l'UEMOA' < https://www3.nd.edu/ ggoertz/rei/rei360/rei360.14tt1.pdf>, accessed 13 October 2018.

West African Economic and Monetary Union (WAEMU) [Union Economique et Monétaire Ouest Africaine] (2001a) 'Protocole Additionnel n.3 instituant les règles d'origine des produits de L'UEMOA', 19 December, <http://www.uemoa.int/sites/default/files/bibliotheque/pages__protocole_additionnel_03.pdf >, accessed 10 February 2017.

WAEMU (2001b) 'Protocole Additionnel n.2 relatif aux Politiques sectorielles de l'UEMOA', $<$ http://www.uemoa.int/fr/protocole-additionnel-ndeg2-relatif-aux-politiques-sectorielles-deluemoa>, accessed 23 March 2019.

WAEMU (2001c) 'Acte additionnel n. 03 portant adoption de la politique agricole de l'UEMOA', accessed 23 March 2019.

WAEMU (2003) 'Traite Modifié de l'Union Economique et Monétaire Ouest Africaine', 29 January, <http://www.uemoa.int/fr/le-traite-modifie>, accessed 10 February 2017. WAEMU (2016a) 'Vingt-cinquième rapport de l'Observatoire des Pratiques Anormales (OPA): Rapport annuel de l'année 2015', June, <http://patronat.bf/wpcontent/uploads/2016/07/Rapport-annuel-OPA_2015.pdf>, accessed 10 February 2017. 
WAEMU (2016b) Rapport semestriel d'exécution de la surveillance multilatérale, June,

$<$ http://www.uemoa.int/sites/default/files/bibliotheque/rapport_semestriel_d_execution_de_la _surveillance_multilaterale_juin_2016.pdf $>$, accessed 10 February 2017. 